\title{
The Dependency of Coastal Livelihood on Forest Resources, and Alternative Options in the Periphery of the Sundarbans Reserve Forest, Patharghata, Bangladesh
}

\author{
Abdul Alim Shaikh1, Mousumi Halder', Mohammad Badrul Alam Talukder², Sk. Mohibullah', \\ Sanjoy Saha ${ }^{3 *}$ \\ ${ }^{1}$ Climate Change Program, Christian Commission for Development in Bangladesh (CCDB), Dhaka, Bangladesh \\ ${ }^{2}$ Royal Danish Embassy, Dhaka, Bangladesh \\ ${ }^{3}$ Institute for Integrated Studies on the Sundarbans and Coastal Ecosystems (IISSCE), Khulna University, Khulna, Bangladesh \\ Email: *sanjoyfwt@yahoo.com
}

How to cite this paper: Shaikh, A. A. Halder, M., Talukder, M. B. A., Mohibullah, Sk., \& Saha, S. (2021). The Dependency of Coastal Livelihood on Forest Resources, and Alternative Options in the Periphery of the Sundarbans Reserve Forest, Patharghata, Bangladesh. Open Journal of Forestry, 11, 398-414.

https://doi.org/10.4236/ojf.2021.114024

Received: March 9, 2021

Accepted: October 25, 2021

Published: October 28, 2021

Copyright ( 2021 by author(s) and Scientific Research Publishing Inc. This work is licensed under the Creative Commons Attribution International License (CC BY 4.0).

http://creativecommons.org/licenses/by/4.0/ (c) (i) Open Access

\begin{abstract}
Dependency on forest resources poses a threat to the environment in $\mathrm{Pa}$ tharghata, Bangladesh. Therefore, this study explores the role of forest resource in the life and livelihood of coastal people as well as to understand the effectiveness of forest and status of forest dependency in and around south-central coast in Patharghata, Bangladesh. We collected data randomly from 105 household heads through both open and close-ended questionnaire. To investigate the forest dependency and people's perception regarding alternative solutions, Microsoft excel software program has been applied. The findings reveal that usage of fuelwood in cooking, housing structure, fish catching, honey \& fodder collection significantly contributes to household dependency on forest resources, while other variables seem to be insignificant. Our study amplifies that the share of forest income to the total household income was only $19 \%$ while other earning sources provided $81 \%$ income. The result shows that respondent people collect forest resources primarily for cooking purpose with a share of $71 \%$ where $9 \%$ forest resources are collected as fodder followed by $8 \%$ forest resource collection as food and sheltering purposes. Moreover, the study found that using alternative cooking system, artificial instruments, declaring the forest as tourist spot, changes in housing structure, occupation are some effective options to reduce forest dependency. The study concludes that these alternative options need more financial and other support from the government, non-government and other civil society organizations to cut down forest resource dependency.
\end{abstract}




\section{Keywords}

Forest Resource Dependency, Biodiversity Conservation, Sundarban Reserve Forest, Coastal Livelihood

\section{Introduction}

Globally mangroves are important forest resources for the coastal people as it provides diversified benefits to human beings (economic, ecological and cultural) to support their livelihood activities (Ewel et al., 1998; Glaser et al., 2003; Moberg \& Rönnbäck, 2003; Rönnbäck et al., 2007; Barbier et al., 2011; Warren-Rhodes et al., 2011). Hundreds of millions of insolvent people around the globe have a direct or indirect dependency on mangroves for their livelihoods and wellbeing (FAO, 2020b). It provides food security, fishery products and timber and non-timber products for their consumption as well as generates income to meet other life-supporting requirements for the coastal people (Hussain \& Badola, 2010; Richman, 2002; Shervette et al., 2007; Walters et al., 2008). Additionally, many developing countries of the world meet up to $90 \%$ of their energy requirements using fuelwood (World Bank, 2004; Abdullah et al., 2016; FAO, 2020a). Moreover, it is considered as a natural barricade against cyclones and tsunamis shielding lives and property of the coastal people (Alongi, 2008; Badola \& Hussain, 2005; Dahdouh-Guebas et al., 2005; Dahdouh-Guebas \& Koedam, 2006; Das \& Vincent, 2009; McIvor et al., 2013; Sathirathai \& Barbier, 2001; Walters, 2003, 2004). A recent study reported that $80 \%$ of people in developing countries have a dependency on NTFPs for their primary and nutritional needs (Dash et al., 2016).

Unfortunately, the mangrove area experiences a sharp decrease of $35 \%$ in the last 2 decades and it is still declining at a $2.1 \%$ rate per year (Cornforth et al., 2013). The reduction rate is more pronounced in developing countries due to anthropogenic pressure (Duke et al., 2007). The rapid degradation and depletion of mangroves have impacted the livelihoods and wellbeing of the local communities (Béné et al., 2001; Midmore \& Whittaker, 2000; Scherr, 2000; Kesavan \& Swaminathan, 2006). Natural dependency is coming under dynamic pressure chiefly for high population growth (Barbier, 2005; Hecht et al., 2012). The case is worse in Bangladesh as more than 35 million people live in the coastal area of Bangladesh, representing $29 \%$ of the total population (Ahmad, 2019) and more than half of this coastal (nearly 52\%) of people directly depend on forest resources for their livelihoods (Islam \& Rahman, 2015).

Livelihood implies the capabilities, assets and activities required as a means of living (Chambers \& Conway, 1992). Livelihood should comply with the conservation and management of natural resources to sustain ecological and social system oscillations (Allison \& Horemans, 2006). Poverty and forest dependence are interrelated in multiple and potentially conflicting ways (Nerfa et al., 2020). 
High forest dependency together with poverty may indicate a scarcity of alternative livelihoods or a marginal economic valuation of forest products (Angelsen \& Wunder, 2003). Again, forests act as a safety net in times of unexpected scarcity or as gap fillers in times of regular shortfall (Angelsen \& Wunder, 2003, Shackleton \& Shackleton, 2004; Paumgarten, 2005). In both the case, impoverished household tends to be more dependent on forest products (Reyes, Nelson, \& Zerriffi, 2018). As a result, the nexus between forest dependency and conservation of natural resources has become a considerable concern of researchers to understand the factors of household dependence on forest resources for the sustainability of forest resources and biodiversity conservation.

The Sundarbans, the world's largest contiguous mangrove forest, is situated in between Bangladesh (59\%) and India (Chaudhuri \& Choudhury, 1994). Its designation as a Ramsar Site and a World Heritage Site indicates the global conservation value of the forest. Economic incentives, property rights and participation in-management process significantly influence the sustainable management of mangrove ecosystems (Walters et al., 2008). To provide economic incentives, in the form of alternative income-generating activities, livelihood analysis is a very important task as it enables the targeted involvement of people to reduce forest dependency and to ensure sustainable management of forest resources by including them in the management aspect (Fikir et al., 2016; Hussain et al., 2018). It will also help policy makers, researchers and professionals to develop diversified livelihood options and encourage sustainable use of forest resources for bringing balance between forest dependency and conservation of resources (Mmbando \& Baiyegunhi, 2016). However, few attempts were taken to understand the livelihood perspectives of the Sundarbans. Therefore, this study aims to determine: 1) What factors influence the household's dependency on forest products? 2) What extent the household depends on forest resources? The present status of forest resource dependency and 3) What are the alternative options for reducing forest resource dependency.

\section{Research Methodology}

In this research, we followed both qualitative and quantitative methods for data collection. In primary data collection, we used three methods: questionnaires survey, Focus Group Discussions (FGD) and Key Informant Interviews (KII) (Figure 1). The questionnaire has developed in both ways i.e., open and close-ended and used to collect information from Households respondents of the research area. FGD method used to have an in-depth understanding of forest dependency and alternative solutions. During the research period, three FGD conducted with local people. KII methods used to get information about forest dependency and alternative solutions from different stakeholders who are well-connected and informed about the local community such as forest range officer, forest bit officer, Union Parishad chairman and member, local influential person and teachers. 


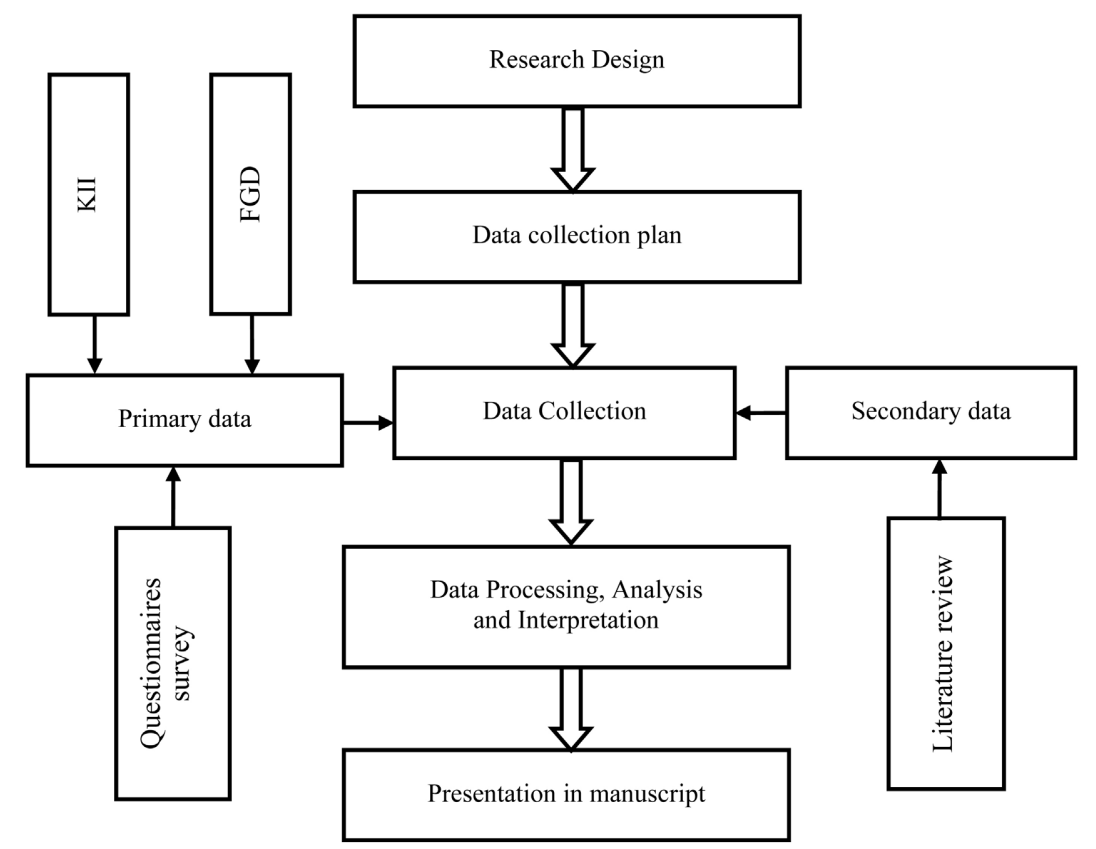

Figure 1. Schematic diagram of this Study. ${ }^{\star}$ FGD (Focus group discussion); KII (Key Informant Interviews).

\subsection{Study Area}

We conducted this study in three villages of Patharghata Upazila of Barguna coastal districts in Bangladesh, namely Tengra, Padma and Horinbaria (Figure 2). The Patharghata Upazila population is 163,927 out of this 80,544 are male and 83383 are female (BBS, 2011). These villages are vulnerable to different natural disasters because of their proximity to the Bay of Bengal, surrounded by Bishkhali and Boleswar River. These area's major hazards are flood, storm surge, cyclone, salinity intrusion, riverbank erosion, and waterlogging. The people's vulnerability to these disasters has intensified due to the dense population and poverty (Rahim et al., 2018).

Moreover, these villages are connected with Sundarbans Reserve Forest (SFR), which is declared as "Ecological Critical Area (ECA)" (Polin \& Alam, 2020). So the dependency of people on SFR forest exists and at the same time as ECA, so we have to find alternative solutions for reducing dependency and considering this dependency and vulnerability, this area is selected as a study area.

\subsection{Determination of Sample Size}

The determination of the sample size was based on Yamane's formulas for the study. The total population of three villages (Tengra, Padma and Horinbaria) is 9640, where the average household population is 4 (BBS-2011).

$$
\begin{aligned}
& \text { Sampling Size }{ }^{*} n=\frac{N}{1+N e^{2}} \\
& =\frac{9640}{1+9640 \times 0.05^{2}}
\end{aligned}
$$




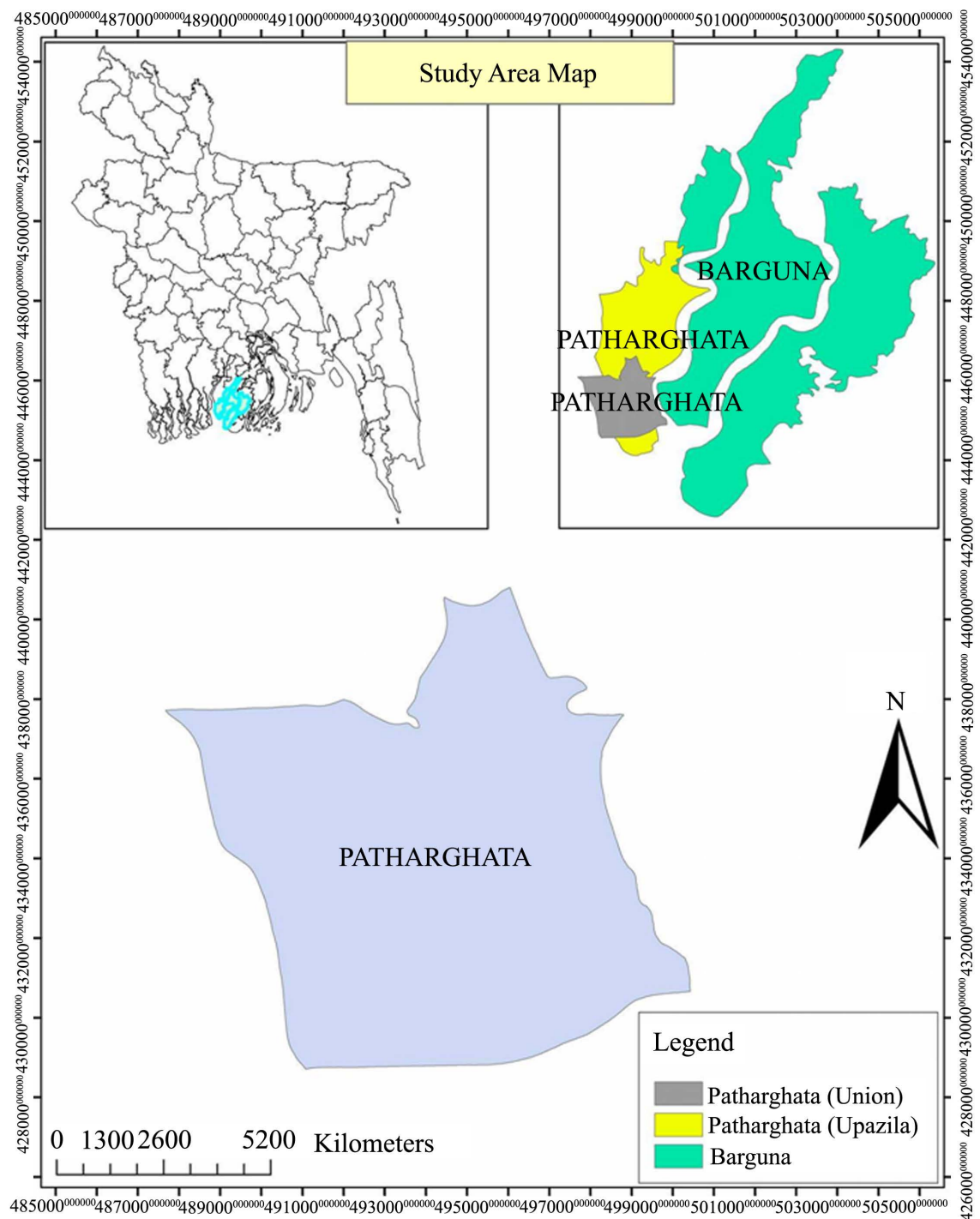

Figure 2. Study area map of Patharghata.

$$
\begin{aligned}
& =387.56 \\
& =388 / 4=97[4=\text { Average household population }] \\
& =97
\end{aligned}
$$

where,

${ }^{*} n$ = Sampling size;

$N=$ Total population in three villages;

$e=$ sampling error $( \pm 5 \%)$.

For this study, 97 questionnaire surveys are the standard sampling size but for the more effective and stability of data, continued 105 (average population per household is 4) household questionnaire survey.

\subsection{Data Analysis Method}

Different tables, charts and diagrams are used for processing the relevant data. MS Excel software program has been applied for showing statistical tests and 
analysis.

\subsection{Forest Resource Dependency Analysis}

Forest dependency of households in the periphery of the Sundarbans Reserve Forest (SRF) has been calculated as the ratio of monthly income received from the forest in compare with the monthly household's income. Total household's income has been calculated as the combination of all income generated from forest resource collection and household's primary income sources like fishing, agriculture, day labour, business and job holder. Fuelwood, fish, fodder, honey, shelter wood, fruits and Nypa fruticans leaves are the ingredients of forest resource income. Items data collected from the forest has been recorded for each household. After that, data has been computed and converted into monetary value based on unit, the resource collected amount, frequency in every month, resource available in months and local market price (Table 1). Then we count the monetary value of all resource collected in a year and convert it to a monthly basis because many of the forest resource items are available for a specific month/season (Table 1). Finally, we compare this forest resource income with total income to find the dependency status.

\section{Result}

\subsection{Respondent Age and Sex Ratio}

In the study area, we applied random sampling methods and after analysis it has been found that, among respondents, $76 \%$ of respondents were male and $24 \%$ were female (Figure 3). We consider a person as respondent whose age ranges from 18 to 80 years old. The graph shows that about $42 \%$ data were collected from 35 - 44 ages people, $18 \%$ from 45 - 54 age, 16\% from 25 - 34 ages, $9 \%$ from 55 - 64 ages, $6 \%$ from 65 - 74 ages, $5 \%$ from less than 25 and only $4 \%$ data collected from age range $75-84$.

Table 1. Forest resource collection computation example.

\begin{tabular}{|c|c|c|c|c|c|c|c|}
\hline $\begin{array}{l}\text { Resource } \\
\text { name }\end{array}$ & Unit & $\begin{array}{l}\text { Amount of collected } \\
\text { resource/day } \\
(\text { Average })\end{array}$ & $\begin{array}{l}\text { Local market } \\
\text { price }(\mathrm{BDT})\end{array}$ & $\begin{array}{c}\text { Frequency } \\
\text { average } \\
\text { (times/month) }\end{array}$ & $\begin{array}{c}\text { No. of Collection } \\
\text { month in a year }\end{array}$ & $\begin{array}{c}\text { Year total } \\
\text { (multiplication of } \\
\text { previous } 3 \text { column) }\end{array}$ & $\begin{array}{c}\text { Average } \\
\text { Monthly } \\
\text { total }\end{array}$ \\
\hline Fuelwood & $\mathrm{Kg}$ & 150 & 600 & 8 & 12 & 57,600 & 4800 \\
\hline Fish & $\mathrm{Kg}$ & 2.5 & 400 & 8 & 12 & 38,400 & 3200 \\
\hline Shelter wood & Piece & 8 & 870 & 4 & 3 & 10,440 & 870 \\
\hline Fodder & Sack & 12 & 360 & 8 & 10 & 28,800 & 2400 \\
\hline Fruits & $\mathrm{Kg}$ & 5 & 500 & 5 & 4 & 10,000 & 833 \\
\hline Honey & $\mathrm{Kg}$ & 10 & 3000 & 6 & 4 & 72,000 & 6000 \\
\hline Hogla Patha & Faggot (Ati) & 18 & 2000 & 12 & 1 & 24,000 & 2000 \\
\hline Goal tree & Pon (local) & 10 & 550 & 3 & 2 & 3300 & 275 \\
\hline Vegetable & $\mathrm{Kg}$ & 1.5 & 10 & 7 & 12 & 840 & 70 \\
\hline
\end{tabular}




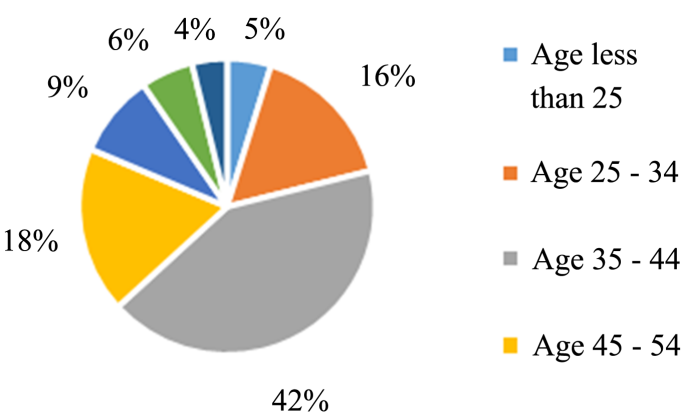

Figure 3. Age of respondents.

\subsection{Education Qualification of Responder}

Education is considered as a catalyst for enhancing desired social change, economic growth and human development. The graph illustrates the education level of the respondent population of the study area in five categories.

The graph shows that most of the population of the study area is illiterately followed by primary and secondary level of education while attending higher secondary and graduation level study are significantly low. In the study area more than $40 \%$ people are illiterate, about $30 \%$ people complete primary educations (Grade 1 - 5), and about 20\% people complete secondary education (Grade 6 - 10). But unfortunately, the rate of attending higher secondary (Grade 11 - 12) and undergraduate education decreased to $7 \%$ and 3\% (Figure 4). Overall, we can see that a significant number of respondents have no education while the rate of attending education goes down as the level increase. There is a positive correlation between education level and monthly income, but this is a very weak relationship.

\subsection{Housing Structure}

The below graph shows the housing structures of the respondents of the study area. As the figure shows, most of the respondents live in timber houses followed by semi-pacca and pacca. Around $90 \%$ of the respondents' houses are made of wood called Kacha house, while around $8 \%$ of houses are semi-pacca made of wood and concrete (Figure 5). On the other hand, only $3 \%$ of houses are built by engineering materials. From the graph, it is clear that forest is a significant source of housing materials for most of the people of the study area.

\subsection{Occupational Sources}

The graph below illustrates different occupations uphold by respondent population. Most of the people's living is directly dependent on natural resources compare to other earning sources. Half of the total respondent's mention fishing as their main income source, while agriculture provides living to $23 \%$ people (Figure 6). Around 19\% of respondents are day labour, while $6 \%$ of respondent's mention business as their main occupation, and only $2 \%$ of respondents are job holder. 


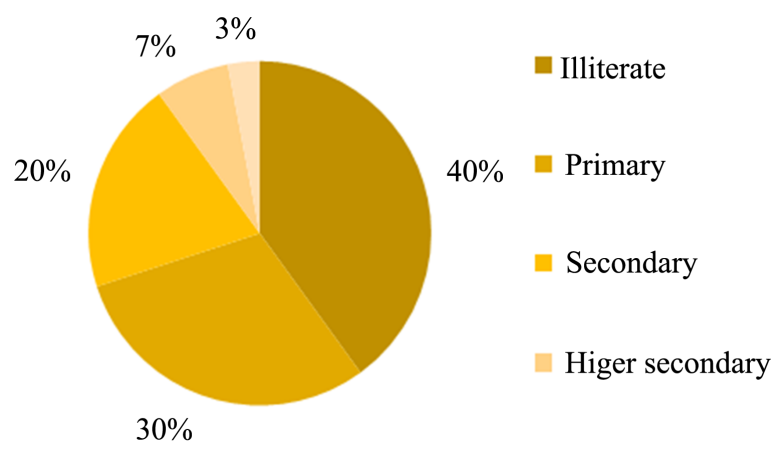

Figure 4. Education qualification of responder.

Housing Structure

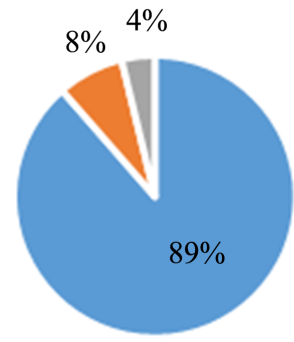

Kacha

- Semi pacca

Pacca

Figure 5. Housing structure of respondents.

Income Distribution

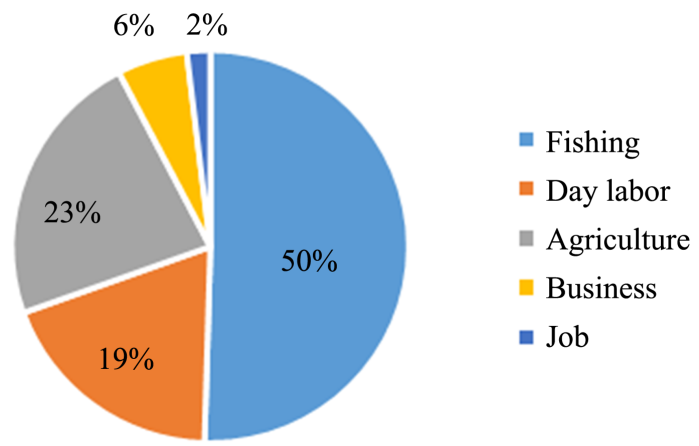

Figure 6. Occupation of the respondent.

\subsection{Household Income Status}

Following graph shows the income status of respondents in the range of BDT 5000 to 20,000 . It has been found that most of the people's monthly income range is BDT $5001-10,000$ followed by up to BDT 15,000 and less than BDT 5000 (Figure 7). 60\% respondent's income range is BDT 5001 to 10,000 while $17 \%$ of people's income range is BDT $10,001-15,000$ and $16 \%$ of people earn less than BDT 5000. Only $6 \%$ of people are earning range is BDT 15,001 - 20,000. Earning above BDT 20,000 is drastically low, which is merely $1 \%$. The average income of the respondents per month is BDT 9457. Henceforth, most of people's daily expenditure is about BDT 315 (USD 3.72). 


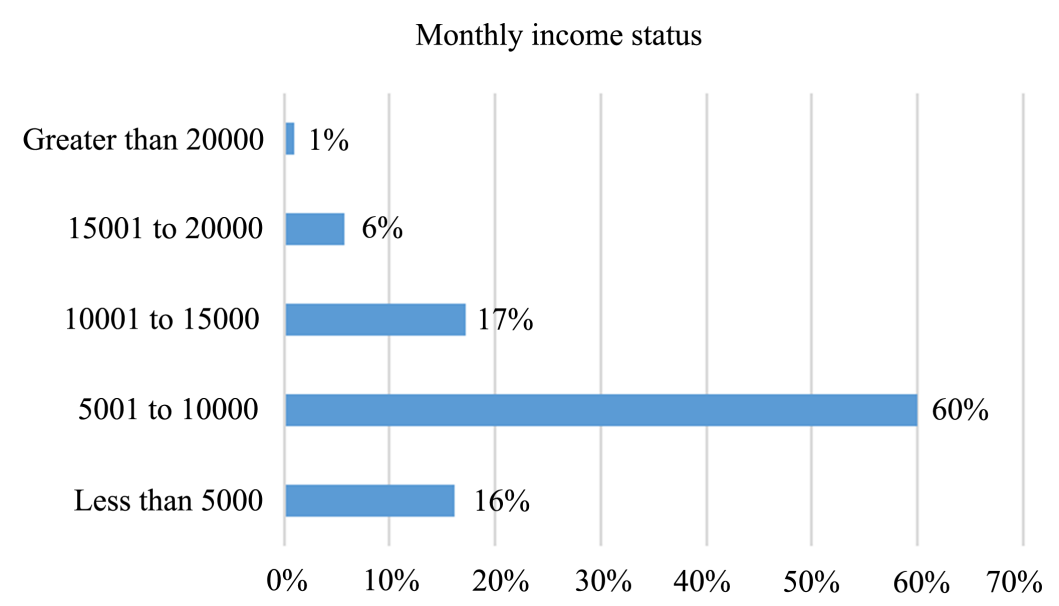

Figure 7. Household income status.

\subsection{Purposes of Forest Resource Collection}

People living nearby woods are dependent on forest resources for many reasons. The graph shows the purposes for which forest resources are collected. $71 \%$ of resources are collected for cooking purpose. People also collect fodder for their cattle, where the percentage is 9 . For food and shelter, $8 \%$ of forest resources are collected (Figure 8). In the case of medicine and commercial purpose, consecutively $3 \%$ and $2 \%$ of resources are collected. It clearly states that forest resources are mainly used as cooking fuel rather than food, fodder and other apparently essential purposes.

\subsection{Percentage of Forest Resource Collection from Forest}

The graph illustrates the percentage of the respondents' monthly income from the collected forest resources. It shows seven categories of resources for which forest is a significant provider. $36 \%$ monthly income comes from fuelwood followed by fish, fodder and honey, which consecutively contribute $25 \%, 14 \%$ and $10 \%$ income out of total income generation from forest resources (Figure 9). At the same time, people earn from shelterwood, fruits and hogla pata collected from the forest that successively provides $7 \%, 5 \%$ and $2 \%$ income. It shows that the forest provides a partial income source for the surrounding people.

\subsection{Forest Resource Dependency}

The graph shows the result after the interpretation of total monthly income and income from forest resources. It shows that $19 \%$ of respondents earn their living from forest resources, while other earning sources provide $81 \%$ income (Figure 10). It indicates that people are still dependent on forest resources for many reasons. But this trend should not be continued for natural forest preservation.

\subsection{Alternative Options for Reducing Forest Dependency (People Perception)}

In the study area, people practice some options which are effective to reduce 
Purpose of forest resource collection

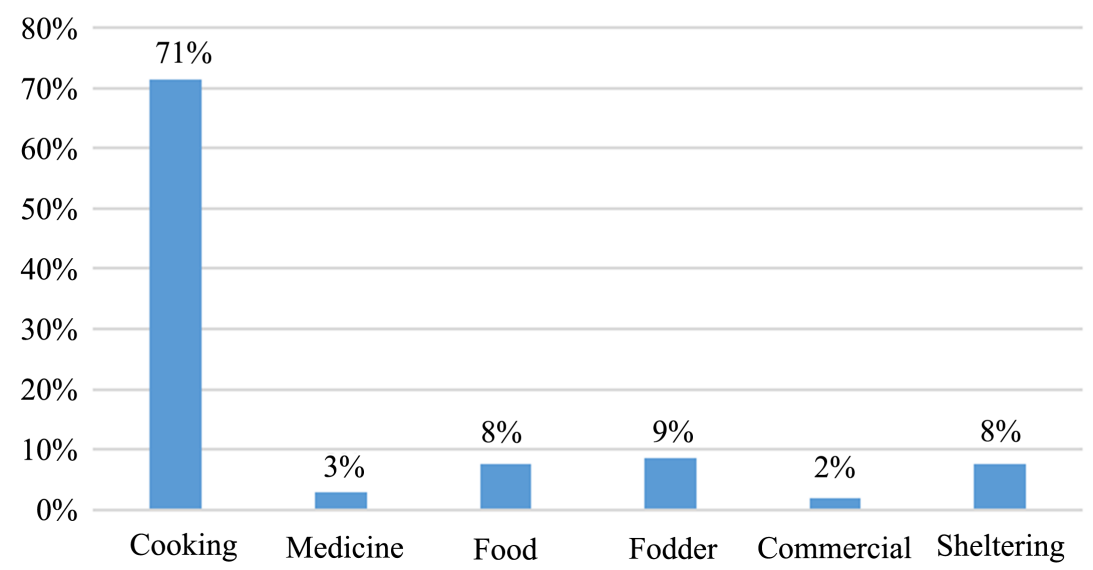

Figure 8. Purpose of forest resource collection.

Percenrage of monthly income from forest resources

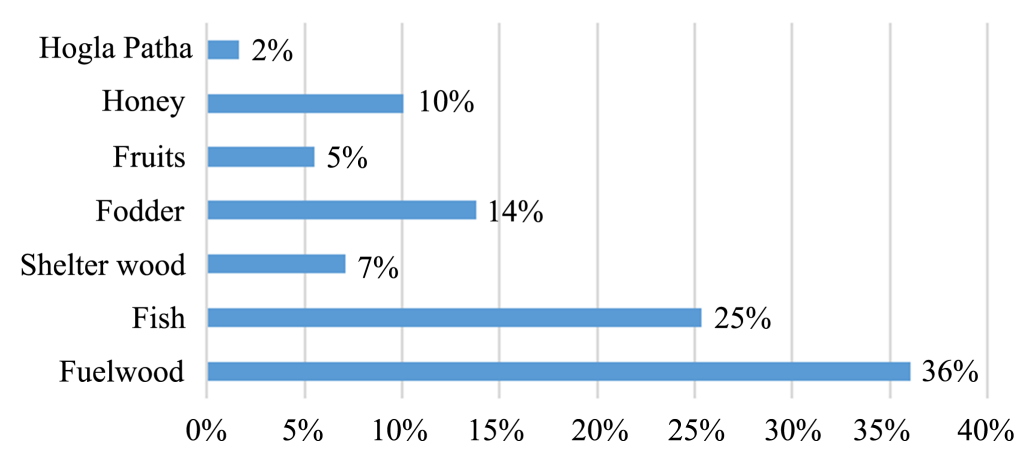

Figure 9. Percentage of forest resource collection from forest.

Forest resource dependency status

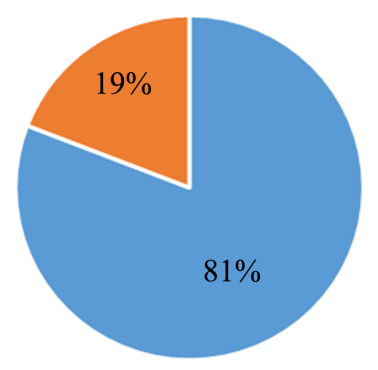

- Income form other source $\quad$ " Income form forest resource

Figure 10. Forest resource dependency status.

forest resource dependency. The following graph shows several potential alternative options that people are using and could use to reduce forest dependency. $75 \%$ of people said that they are using alternative cooking systems to reduce fuelwood use in daily cooking activities (Figure 11). As of, 58\% respondent 


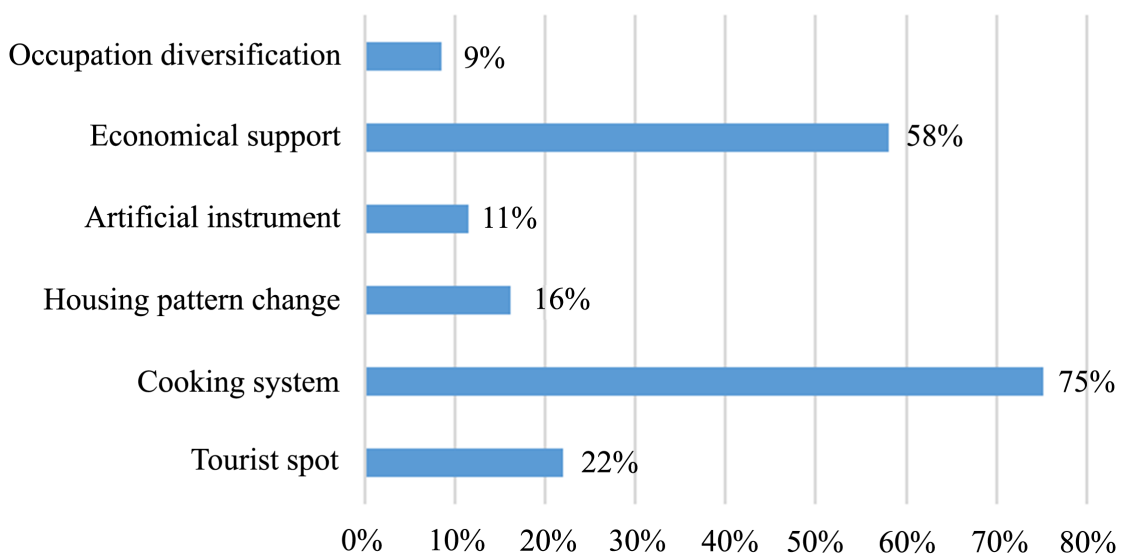

Figure 11. Alternative options, people's perception.

stated that economic support could decrease forest resource dependency. $22 \%$ of people opined that declaring the forest as tourist spot could have contributed to increasing their income and reducing forest resource dependency. Likely, changing housing patterns, using artificial instruments and diversifying livelihood options were highlighted as alternative options to decrease forest resource dependency. Overall, we can see that these alternative options would add great value to minimize dependency on forest resources.

\section{Discussion}

The study population encompasses those residents living in the surrounding area of the forest. So naturally, they have a connection with the forest. It paves the way of mutual dependency between forest and adjacent community. We have seen that around 90 percent of houses in our study area are made of wood from the result. This information clearly indicates that the forest is a significant provider of housing materials.

Exploring the inter-dependency between education and forest resource collection, the result shows us that education plays hardly any role regarding forest resource dependency for the people living nearby the woods. It is assumed that as the education level increases, dependency on forest resources will be reduced (Ali et al., 2020). Nonetheless, the result illustrates that most of the people from the adjacent area regardless of their educational status depend on forest resources. There are several reasons behind it. One of the most important factors behind it is that these people live in this area for generation after generation. They are historically habituated with nature which reluctant them to go outside their own community. This area is not industrially developed also. As a result, employment opportunity in industry is relatively less here compared to the suburban area. And in case of employment in this area, a minimum level of education level which means up to higher secondary level (grade 12) is required. It turns out that the adjacent area of forest cannot provide decent jobs for highly 
educated people which cause them lack of interest in education. This indifference towards education becomes grounded with local perspectives over the times resulted in settling the lives and livelihoods center to this area.

Study shows that the average income of a household is BDT 9457 from which BDT 2350 comes from forest resource collection. The major area of respondent's income is fishing, agriculture and working as day laborer followed by business and service provider, while it is mentionable that topmost income comes from fishing in that area which covers almost $50 \%$. Hence, it is clear that the forest is not the primary income sources for the study population.

Most of the forest resources collected from the forest are generally used for household consumption purpose. Resources are mainly used for cooking purpose. Literature shows that more than $70 \%$ fuelwood is the main source of cooking for the people who are close to the reserve forest (Adam \& Tayeb, 2014; Rahman et al., 2017; Ali et al., 2020). Apart from this, they also use the resource as food, fodder and for housing materials.

Results show that household's dependency on the forest is $19 \%$, from the relevant study this found from $13 \%$ to $50 \%$, in general, it is around $30 \%$. However, it varies with location, socio-economic conditions and social context (Jain \& Sajjad, 2016; Mukul et al., 2016; Rahman et al., 2017; Ali et al., 2020).

\section{Recommendation}

Forest plays a significant role in human life, particularly in rural people's lives and livelihoods. Over dependency on forest resources, mainly for cooking, building houses, and food, is creating tremendous environmental impacts globally. The study shows some alternative options based on people's perception to reduce forest resource dependency within the coastal community. From the study, we draw the following recommendations that will significantly contribute to lessen dependency on forest resources.

\subsection{Provide Sufficient Cooking Stove}

The community people use some alternative cooking system, but it is not sufficient for reducing the dependency on fuelwood collected from the forest. Some coastal people use biogas, cookers, slender gas, development stoves, and use the friend stove (in Bangla, Bondhu Chula). More support is much needed to publicize alternative cooking system, which is environment friendly and easy to use \& manage.

\subsection{Alternative Material Use in House Construction}

Kacha house or shack needs more timber and non-timber forest products. This can be reduced by transforming the housing structure into pacca house, the main materials of which are brick, cement etc. This change will save excessive extraction of timber from the forest. Additionally, the pacca house is more disaster resilient. Though some affluent people build pacca house, most of the 
people of this area do not afford the costing of pacca house. For this, the following steps are recommended:

- Government as well as other development agencies should provide incentives to build pacca house.

- A number of demo pacca house, which are also designed in disaster resilient pattern, can be demonstrated in this area.

- Mass awareness raising on alternative housing material usages can play significant role to reduce forest resource dependency for housing purpose.

\subsection{Create Occupation Diversification}

Diversification of livelihoods is one of the sustainable solutions to reduce the forest dependency in the coastal zone of Pathorghata, Barguna. It will greatly contribute to conserve forest resources. Simultaneously, diversified livelihoods lessen risk and seasonality of natural resource dependent people. As a result, this can ensure a continuous earning throughout the year.

- Different jobs, business, farming and non-farming related occupation are some viable options that could be introduced among people.

- More supports from government and other development agencies are needed to encourage people for occupational diversification.

\section{Conclusion}

The lives and livelihoods of coastal people revolve around forest resources. This paper investigates forest resource dependency of people living in south-central coast of Pathorghata, Bangladesh. People living within or near the coastal forest mostly depend on its resources to fulfill many of their fundamental needs such as food, housing materials, medicinal herbs, fuel, fishing and many other items for employment and commerce. Woods provide basic material for houses, furniture and local boats. Half of the total respondent population earns their livelihoods from fishing in the forest. In exploring the purposes of forest resource collection, most of the forest materials used as cooking fuel followed by fodder, food, sheltering, medicine and commercial purposes. After the interpretation of data, the result shows that $19 \%$ respondents earn their living from forest resources, while other earning sources provide $81 \%$ income. The findings conclude that though most of the respondent's earning comes from sources which are not directly connected to forest, the percentage of people dependent on forest assets is a matter of concern for forest conservation.

Introducing alternative options to reduce the forest resource dependency can play a significant role. The factors behind forest resource dependency, as identified in this research survey, should be addressed considering the needs of community people. This study suggested four sustainable ways of forest resource dependency reduction based on local people opinion. These options, i.e., tourist spot related socio-economic development, introduction of alternative cooking system, changes in housing structure and livelihood diversification, require ex- 
tensive support from government and other concerned agencies, who are working constantly for the improvement of lives and livelihoods of these marginal people. This will protect our forest and the forest will stand as a natural shield to protect people from natural calamities as well as contribute to conserving environmental stability.

\section{Conflicts of Interest}

The authors declare no conflicts of interest regarding the publication of this paper.

\section{References}

Abdullah, A. N. M., Stacey, N., Garnett, S. T., \& Myers, B. (2016). Economic Dependence on Mangrove Forest Resources for Livelihoods in the Sundarbans, Bangladesh. Forest Policy and Economics, 64, 15-24. https://doi.org/10.1016/j.forpol.2015.12.009

Adam, Y. O., \& Tayed, A. M. E. (2014). Forest Dependency and Its Effect on Conservation in Sudan: A Case of Sarf-Saaid Reserved Forest in Gadarif State. Agriculture \& Forestry, 60, 107-121.

Ahmad, H. (2019). Bangladesh Coastal Zone Management Status and Future Trends. Journal of Coastal Zone Management, 22, 1-7.

Ali, N., Hu, X., \& Hussain, J. (2020). The Dependency of Rural Livelihood on Forest Resources in Northern Pakistan's Chaprote Valley. Global Ecology and Conservation, 22, e01001. https://doi.org/10.1016/j.gecco.2020.e01001

Allison, E. H., \& Horemans, B. (2006). Putting the Principles of the Sustainable Livelihoods Approach into Fisheries Development Policy and Practice. Marine Policy, 30, 757-766. https://doi.org/10.1016/j.marpol.2006.02.001

Alongi, D. M. (2008). Mangrove Forests: Resilience, Protection from Tsunamis, and Responses to Global Climate Change. Estuarine, Coastal and Shelf Science, 76, 1-13. https://doi.org/10.1016/j.ecss.2007.08.024

Angelsen, A., \& Wunde, S. (2003). Exploring the Forest-Poverty Link: Key Concepts, Issues and Research Implications. Centre for International Forestry Research, Paper No. 40.

Badola, R., \& Hussain, S. A. (2005). Valuing Ecosystem Functions: An Empirical Study on the Storm Protection Function of Bhitarkanika Mangrove Ecosystem, India. Environmental Conservation, 32, 85-92. https://doi.org/10.1017/S0376892905001967

Barbier, E. B. (2005). Natural Resources and Economic Development. Cambridge University Press. https://doi.org/10.1017/CBO9780511754036

Barbier, E. B., Hacker, S. D., Kennedy, C., Koch, E. W., Stier, A. C., \& Silliman, B. R. (2011). The Value of Estuarine and Coastal Ecosystem Services. Ecological Monographs, 81, 169-193. https://doi.org/10.1890/10-1510.1

BBS (2011). Population and Housing Census 2011. Statistics and Information Division, Ministry of Planning.

Béné, C., Doyen, L., \& Gabay, D. (2001). A Viability Analysis for a Bio-Economic Model. Ecological Economics, 36, 385-396. https://doi.org/10.1016/S0921-8009(00)00261-5

Chambers, R., \& Conway, G. (1992). Sustainable Rural Livelihoods: Practical Concepts for the 21st Century. Institute of Development Studies (UK).

Chaudhuri, A. B., \& Choudhury, A. (1994). Mangroves of the Sundarbans. Volume 1: In- 
dia. International Union for Conservation of Nature and Natural Resources (IUCN).

Cornforth, W. A., Fatoyinbo, T. E., Freemantle, T. P., \& Pettorelli, N. (2013). Advanced Land Observing Satellite Phased Array Type L-Band SAR (ALOS PALSAR) to Inform the Conservation of Mangroves: Sundarbans as a Case Study. Remote Sensing, 5, 224-237. https://doi.org/10.3390/rs5010224

Dahdouh-Guebas, F., \& Koedam, N. (2006). Coastal Vegetation and the Asian Tsunami. Science, 311, 37-38. https://doi.org/10.1126/science.311.5757.37

Dahdouh-Guebas, F., Jayatissa, L. P., Di Nitto, D., Bosire, J. O., Lo Seen, D. et al. (2005) How Effective Were Mangroves as a Defence against the Recent Tsunami? Current Biology, 15, R443-R447. https://doi.org/10.1016/j.cub.2005.06.008

Das, S., \& Vincent, J. R. (2009). Mangroves Protected Villages and Reduced Death Toll during Indian Super Cyclone. Proceedings of the National Academy of Sciences, 106, 7357-7360. https://doi.org/10.1073/pnas.0810440106

Dash, M., Behera, B., \& Rahut, D. B. (2016). Determinants of Household Collection of Non-Timber Forest Products (NTFPs) and Alternative Livelihood Activities in Similipal Tiger Reserve, India. Forest Policy and Economics, 73, 215-228.

https://doi.org/10.1016/j.forpol.2016.09.012

Duke, N. C., Meynecke, J. O., Dittmann, S., Ellison, A. M., Anger, K., Berger, U., Dahdouh-Guebas, F. et al. (2007). A World without Mangroves? Science, 317, 41-42. https://doi.org/10.1126/science.317.5834.41b

Ewel, K., Twilley, R., \& Ong, J. I. N. (1998). Different Kinds of Mangrove Forests Provide Different Goods and Services. Global Ecology \& Biogeography Letters, 7, 83-94.

https://doi.org/10.2307/2997700

FAO (2020a). Sustainable Charcoal Production for Food Security and Forest Landscape Restoration. Skukuza-Mpumalanga, South Africa.

FAO (2020b). Forests and Poverty Reduction.

http://www.fao.org/forestry/livelihoods/en

Fikir, D., Tadesse, W., \& Gure, A. (2016). Economic Contribution to Local Livelihoods and Households Dependency on Dry Land Forest Products in Hammer District, Southeastern Ethiopia. International Journal of Forestry Research, 2016, Article ID: 5474680. https://doi.org/10.1155/2016/5474680

Glaser, M., Berger, U., \& Macedo, R. (2003). Local Vulnerability as an Advantage: Mangrove Forest Management in Pará State, North Brazil, under Conditions of Illegality. Regional Environmental Change, 3, 162-172. https://doi.org/10.1007/s10113-003-0057-4

Hecht, B. C. et al. (2012). Genetic Architecture of Migration-Related Traits in Rainbow and Steelhead Trout, Oncorhynchus mykiss. G3: Genes Genomes Genetics, 2, 1113-1127. https://doi.org/10.1534/g3.112.003137

Hussain, N., Rigoni, U., \& Cavezzali, E. (2018). Does It Pay to Be Sustainable? Looking inside the Black Box of the Relationship between Sustainability Performance and Financial Performance. Corporate Social Responsibility and Environmental Management, 25, 1198-1211. https://doi.org/10.1002/csr.1631

Hussain, S. A., \& Badola, R. (2010). Valuing Mangrove Benefits: Contribution of Mangrove Forests to Local Livelihoods in Bhitarkanika Conservation Area, East Coast of India. Wetlands Ecology and Management, 18, 321-331.

https://doi.org/10.1007/s11273-009-9173-3

Islam, S. A., \& Rahman, M. M. (2015). Coastal Afforestation in Bangladesh to Combat Climate Change Induced Hazards. Journal of Science Technology and Environment 
Informatics, 2, 13-25. https://doi.org/10.18801/jstei.020115.12

Jain, P., \& Sajjad, H. (2016). Household Dependency on Forest Resources in the Sariska Tiger Reserve (STR), India: Implications for Management. Journal of Sustainable Forestry, 35, 60-74. https://doi.org/10.1080/10549811.2015.1099108

Kesavan, P. C., \& Swaminathan, M. S. (2006). Managing Extreme Natural Disasters in Coastal Areas. Philosophical Transactions of the Royal Society A: Mathematical, Physical and Engineering Sciences, 364, 2191-2216. https://doi.org/10.1098/rsta.2006.1822

Lacuna-Richman, C. (2002). The Socioeconomic Significance of Subsistence Non-Wood Forest Products in Leyte, Philippines. Environmental Conservation, 29, 253-262. https://doi.org/10.1017/S0376892902000152

McIvor, A. L., Möller, I., Spencer, T., \& Spalding, M. (2013, September). Mangroves as a Sustainable Coastal Defence. 7th International Conference on Asian and Pacific Coasts (APAC), Bali, September 2013, 24-26.

Midmore, P., \& Whittaker, J. (2000). Economics for Sustainable Rural Systems. Ecological Economics, 35, 173-189. https://doi.org/10.1016/S0921-8009(00)00195-6

Mmbando, F. E., \& Baiyegunhi, L. J. (2016). Socio-Economic and Institutional Factors Influencing Adoption of Improved Maize Varieties in Hai District, Tanzania. Journal of Human Ecology, 53, 49-56. https://doi.org/10.1080/09709274.2016.11906955

Moberg, F., \& Rönnbäck, P. (2003). Ecosystem Services of the Tropical Seascape: Interactions, Substitutions and Restoration. Ocean \& Coastal Management, 46, 27-46. https://doi.org/10.1080/09709274.2016.11906955

Mukul, S. A., Rashid, A. Z. M. M., Uddin, M. B., \& Khan, N. A. (2016). Role of Non-Timber Forest Products in Sustaining Forest-Based Livelihoods and Rural Households' Resilience Capacity in and around Protected Area: A Bangladesh Study. Journal of Environmental Planning and Management, 59, 628-642. https://doi.org/10.1080/09640568.2015.1035774

Nerfa, L., Rhemtulla, J. M., \& Zerriffi, H. (2020). Forest Dependence Is More than Forest Income: Development of a New Index of Forest Product Collection and Livelihood Resources. World Development, 125, Article ID: 104689. https://doi.org/10.1016/j.worlddev.2019.104689

Paumgarten, F. (2005). The Role of Non-Timber Forest Products as Safety-Nets: A Review of Evidence with a Focus on South Africa. GeoJournal, 64, 189-197. https://doi.org/10.1007/s10708-005-5647-x

Polin, F., \& Alam, D. (2020). Enhancing Community Participation in Forest Management: Case Study of the Sundarbans, Bangladesh.

Rahim, M. A., Siddiqua, A., Nur, M. N. B., \& Zaman, A. M. (2018). Community Perception on Adverse Effects of Natural Hazards on Livelihood and Enhancing Livelihood Resiliency: A Case Study at Patharghata Upazila, Barguna. Procedia Engineering, 212, 149-156. https://doi.org/10.1016/j.proeng.2018.01.020

Rahman, M. M., Mahmud, M. A. A., Ahmed, F. U., \& Deb, R. (2017). Developing Alternative Income Generation Activities Reduces Forest Dependency of the Poor and Enhances Their Livelihoods: The Case of the Chunati Wildlife Sanctuary, Bangladesh. Forests Trees and Livelihoods, 26, 256-270.

https://doi.org/10.1080/14728028.2017.1320590

Reyes, R., Nelson, H., \& Zerriffi, H. (2018). Firewood: Cause or Consequence? Underlying Drivers of Firewood Production in the South of Chile. Energy for Sustainable Development, 42, 97-108. https://doi.org/10.1016/j.esd.2017.10.006

Rönnbäck, P., Crona, B., \& Ingwall, L. (2007). The Return of Ecosystem Goods and Ser- 
vices in Replanted Mangrove Forests: Perspectives from Local Communities in Kenya. Environmental Conservation, 34, 313-324. https://doi.org/10.1017/S0376892907004225

Sathirathai, S., \& Barbier, E. B. (2001). Valuing Mangrove Conservation in Southern Thailand. Contemporary Economic Policy, 19, 109-122. https://doi.org/10.1111/j.1465-7287.2001.tb00054.x

Scherr, S. J. (2000). A Downward Spiral? Research Evidence on the Relationship between Poverty and Natural Resource Degradation. Food Policy, 25, 479-498. https://doi.org/10.1016/S0306-9192(00)00022-1

Shackleton, C., \& Shackleton, S. (2004). The Importance of Non-Timber Forest Products in Rural Livelihood Security and as Safety Nets: A Review of Evidence from South Africa. South African Journal of Science, 100, 658-664.

Shervette, V. R., Aguirre, W. E., Blacio, E., Cevallos, R., Gonzalez, M., Pozo, F., \& Gelwick, F. (2007). Fish Communities of a Disturbed Mangrove Wetland and an Adjacent Tidal River in Palmar, Ecuador. Estuarine, Coastal and Shelf Science, 72, 115-128. https://doi.org/10.1016/j.ecss.2006.10.010

Walters, B. B. (2003). People and Mangroves in the Philippines: Fifty Years of Coastal Environmental Change. Environmental Conservation, 30, 293-303.

https://doi.org/10.1016/j.ecss.2006.10.010

Walters, B. B. (2004). Local Management of Mangrove Forests in the Philippines: Successful Conservation or Efficient Resource Exploitation? Human Ecology, 32, 177-195. https://doi.org/10.1023/B:HUEC.0000019762.36361.48

Walters, B. B., Rönnbäck, P., Kovacs, J. M., Crona, B., Hussain, S. A., Badola, R., Dahdouh-Guebas, F. et al. (2008). Ethnobiology, Socio-Economics and Management of Mangrove Forests: A Review. Aquatic Botany, 89, 220-236.

https://doi.org/10.1016/j.aquabot.2008.02.009

Warren-Rhodes, K., Schwarz, A. M., Boyle, L. N., Albert, J., Agalo, S. S., Warren, R., Duke, N. et al. (2011). Mangrove Ecosystem Services and the Potential for Carbon Revenue Programmes in Solomon Islands. Environmental Conservation, 38, 485-496. https://doi.org/10.1017/S0376892911000373

World Bank (2004). Sustaining Forests: A Development Strategy. The World Bank. 